Available online:

http://journal.imla.or.id/index.php/arabi

IMLA

Arabi : Journal of Arabic Studies, 2 (1), 2017, 37-46

DOI: http://dx.doi.org/10.24865/ajas.v2i1.24

\title{
PEMANFAATAN WORDERSHARE QUIZ CREATOR DALAM PEMBUATAN SOAL-SOAL BAHASA ARAB
}

\author{
Diah Rahmawati As'ari \\ Universitas Negeri Malang \\ E-mail : nadiah_rahma@yahoo.com
}

\begin{abstract}
The development of technology and information give a positive impact on the development of education. Technology and information development provide various softwares to facilitate teachers in developing teaching media and creating attractive evaluation tool. An evaluation inArabic language teaching is to measure the extent to which students master the Arabic materials. Many softwares were developed to be evaluation tool in technology based learning, and of the one is Wordershare Quiz Creator. This software is quiz or test processing program that is easy to use. With this application, it is expected that Arabic language teachers are able to create technologybased Arabic language tests that can attract and improve students' enthusiast in doing the Arabic quiz.
\end{abstract}

Keywords: Wordershare Quiz, test, questions, Arabic language, ICT

\begin{abstract}
Abstrak
Kemajuan teknologi informasi membawa dampak positif bagi kemajuan dunia pendidikan. Kemajuan teknologi dan informasi telah menyediakan berbagai macam perangkat lunak komputer atau software untuk mempermudah dalam membuat media pembelajaran dan membuat alat evaluasi yang menarik. Evaluasi dalam pengajaran bahasa Arab adalah untuk mengukur sejauh mana penguasaasn peserta didik terhadap materi bahasa Arab. Banyak software yang telah dikembangkan sebagai alat evaluasi dalam pembelajaran yang berbasis teknologi informasi dan komunikasi, salah satunya adalah Wondershare Quiz Creator. Software ini adalah program pembuat tes atau kuis yang mudah digunakan. Dengan aplikasi ini, diharapkan guru Bahasa Arab dapat membuat tes bahasa Arab berbasis TIK yang menarik dan meningkatkan semangat peserta didik dalam mengerjakan soal-soal bahasa Arab.
\end{abstract}

Kata Kunci: Wondershare Quiz Creator, tes, soal, bahasa Arab, TIK 


\section{Arabi : Journal of Arabic Studies}

\section{Pendahuluan}

Kemajuan teknologi informasi membawa dampak positif bagi kemajuan dunia pendidikan, khususnya teknologi komputer dan teknologi internet, baik dalam perangkat keras maupun perangkat lunak. Keunggulan teknologi informasi terletak pada faktor kecepatan untuk mendapatkan informasi dan fasilitas multimedia pembelajaran yang menarik, visual dan interaktif. Banyak kegiatan pembelajaran yang dapat dilakukan dengan memanfaatkan teknologi internet (Rolisca dan Achadiyah, 2014:42). Kemajuan teknologi dan informasi sekarang ini telah menyediakan berbagai macam perangkat lunak komputer atau software untuk mempermudah dalam membuat media pembelajaran yang lebih menarik seperti Microsoft Power Point, Adobe Flash, dan software khusus yang digunakan untuk membuat evaluasi seperti Wondershare Quiz Creator.

Evaluasi dalam pembelajaran Bahasa Arab memiliki peran penting untuk mengukur tingkat keberhasilan proses pembelajaran (Ismail, 2016: 267). Untuk melakukan evaluasi dalam pembelajaran Bahasa Arab maka dibutuhkan tes. Menurut Asrori dkk (2012:6) tes adalah jenis alat untuk memperoleh data numerik atau alat untuk melakukan pengukuran dan hasilnya dimanfaatkan sebagai bahan pertimbangan dalam melakukan evaluasi. Saat ini telah berkembang alat evaluasi yang berbasis TIK dapat digunakan untuk mengukur keberhasilan proses pembelajaran Bahasa Arab. Salah satunya adalah pembuatan soal interaktif dengan memanfaatkan software Wondershare Quiz Creator.

Wondershare Quiz Creator merupakan perangkat lunak untuk pembuatan soal, kuis atau tes secara online (berbasis web). Penggunaan Wondershare Quiz Creator dalam pembuatan soal tersebut sangat familiar/user friendly, sehingga sangat mudah digunakan dan tidak memerlukan kemampuan bahasa pemrograman yang sulit untuk mengoperasikannya (Hernawati, 2009: 1). Wondershare Quiz Creator adalah sebuah software yang rancang untuk membuat program evaluasi pembelajaran maupun kuis yang berbasis IT. Software ini dapat dimanfaatkan untuk membantu dan mempermudah dalam membuat kuis atau soal Bahasa Arab dengan menggunakan model-model soal yang ada didalamnya. Wondershare Quiz Creator bisa dimanfaatkan oleh guru atau dosen untuk melakukan evaluasi pembelajaran Bahasa Arab dengan cepat, ringkas, dan menarik bagi peserta didik. Hasil dari evaluasi yang dibuat dapat disimpan dalam format file $s w f$, file $h t m l$ at au file .exe.

Berdasarkan latar belakang di atas, penulis akan membahas pembuatan soal-soal atau pembelajaran bahasa Arab dengan memanfaatkan Wondershare Quiz Creator. Pembahasan akan dimulai dengan mendeskripsikan evaluasi dalam pembelajaranbahasa Arab, evaluasi berbasis TIK, dan pemanfaatan Wondershare Quiz Creator dalam pembuatan soal-soal bahasa Arab.

\section{Tes dalam Pembelajaran Bahasa Arab}

Ada satu prinsip umum dan penting dalam kegiatan evaluasi yaitu adanya triangulasi atau hubungan erat tiga komponen yaitu antara tujuan, kegiatan pembelajaran dan evaluasi (Arikunto, 1999:24). Kegiatan pembelajaran dirancang dengan mengacu pada tujuan yang telah diumuskan. Begitu juga dengan evaluasi. Evaluasi yang disusun juga disesuaikan dengan tujuan dan proses pembelajaran. Evaluasi digunakan dengan mengumpulkan data untuk mengetahui sejauh mana tujuan pembelajaran telah tercapai. untuk melakukan evaluasi maka diperlukan alat atau instrumen yaitu tes.

Tes merupakan alat ukur dalam proses evaluasi. Ruang lingkup tes bahasa dibagi menjadi dua yaitu tes unsur-unsur bahasa dan tes keterampilan bahasa. Adapun tes unsur-unsur bahasa adalah tes ashwat bahasa Arab, mufrodat bahasa Arab, dan tarkib/ qowaid (tata bahasa).Sedangkan tes keterampilan bahasa adalah tes keterampilan istima'(mendengar), keterampilan kalam (berbicara), keterampilan qiro'ah (membaca), keterampilan kitabah (menulis).

Tes bahasa memiliki hubungan dengan kegiatan pembelajaran bahasa. Pembelajaran merupakan proses usaha aktif untuk memperoleh kemampuan berbahasa. untuk mengukur tingkat 
pemerolehan kemampuan berbahasa maka diperluakan tes. Menurut Sudijono (dalam Matsna HS dan Mahyudin, 2012:15) alat evaluasi berfungsi untuk mengukur tingkat perkembangan yang telah dicapai peserta didik setelah mereka menempuh proses pembelajaran dalam jangka waktu tertentu. Alat evaluasi juga merupakan alat pengukur keberhasilan program pembelajaran.

Jenis tes bahasa Arab dapat dilihat dari berbagai kriteria. Djiwandono (dalam Asrori dkk, 2006:84) membagi tes bahaasa atas dasar 10 kriteria yang berbeda yaitu 1) kriteria tujuan penyelenggaraan (tes seleksi, tes penempatan, tes hasil belajar, tes diagnostic, dan tes uji coba), 2) kriteria waktu penyelenggaraan (tes masuk, tes formatif, tes sumatif, pra tes dan post tes), 3) kriteria cara mengerjakan (tes tulis dan tes lisan), 4) kriteria cara penyusunan (tes buatan guru dan tes berstandar), 5) kriteria jumlah peserta (tes perseorangan dan tes kelompok), 6) kriteria bentuk jawaban (tes esai, tes jawaban pendek, dan tes pilihan ganda), 7) kriteria cara penilaian (tes subjektif dan tes objektif), 8) kriteria acuan penilaian (tes bahasa acuan norma, acuan patokan, dan acuan gabungan), 9) kriteria tes bakat bahasa( kemampuan berbahasa, dan tes komponen bahasa), dan 10) kriteria pandangan terhadap bahasa (tes bahasa diskret, integratif, pragmatik, dan komunikatif).

Keberhasilan suatu kegiatan evaluasi akan dipengaruhi oleh keberhasilan evaluator dalam melaksanakan prosedur evaluasi. Prosedur yang dimaksud adalah langkah-langkah pokok yang harus ditempuh dalam kegiatan evaluasi (Arifin, 2014:88). Dalam menyusun soal atau tes bahasa Arab perlu disusun sebuah prosedur. Prosedur ini bertujuan untuk menghasilkan tes bahasa Arab yang valid dan reliable. Prosedur dalam pengembangan evaluasi pembelajaran terdiri at as delapan tahap (Asrori dkk, 2012:64-71).

Tahap Pertama adalah tahap persiapan. Pada tahap ini guru atau pembuat tes melakukan kajian terhadap kurikulum bahasa Arab dan buku pedoman pelaksanaan kurikulum untuk mata pelajaran bahasa Arab. Tahap kedua adalah pemilihan materi tes. Untuk menetapkan materi tes bahasa Arab yang benar-benar selesai dan selektif dapat dilakukan beberapa kegiatan yaitu: a) menentukan komponen dan keterampilan berbahasa yang akan diteskan, misalnya tes kosakata, struktur, membaca, menulis atau tes berbicara, b) menentukan pokok bahasan yang akan diteskan secara representatif (tidak bias dan tidak atas dasar subjektifitas penyusaun tes. Tahap ketiga adalah menentukan bentuk dan jenis tes. Tes komponen bahasa dan kemampuan berbahasa dapat disusun dalam bentuk subjektif dan atau objektif dengan segala variasinya atau jenisnya (kecuali tes keterampilan berbicara yang memiliki perlakuan khusus). Dengan ungkapan lain, tes yang disusun dapat berbentuk objektif dengan jenis pilihan ganda at au salah benar atau dapat pula berbentuk subjektif (esai).Tahapan keempat menentukan jumlah butir tes. Perihal yang harus dipertimbangkan dalam menentukan jumlah butir tes adalah alokasi waktu yang tersedia untuk penyelenggaraan tes. Untuk menentukan berapa jumlah butir tes yang harus disusun sesuai dengan waktu yang tersedia memang tidak ada batasan yang pasti. Tahap kelima adalah menentukan skor. Apabila jumlah butir tes sejumlah 40 (pilihan ganda) dengan skor tertinggi 100 dan semua butir tes diberi bobot skor sama, maka skor untuk jawaban yang benar pada setiap bbutir tes adalah 2,5. Apabila soal yang dibuat, baik yang berbentuk subyektif ataupun obyektif itu setiap butirnya mempunyai tingkat kesulitan dan kompleksitas yang berbeda, maka pihak guru atau pembuat tes dapat memberikan bobot yang berbeda. Tahap keenam adalah membuat kisi- kisi. Kisi- kisi merupakan panduan dari guru dalam menyusun atau mengembangkan suatu tes. Tanpa adanya kisi-kisi yang jelas, maka sulit bagi guru atau pembuat tes dapat menghasilkan sebuah tes yang memenuhi kriteria tes yang baik, yaitu suatu tes yang valid dan reliabel. Tahap ketujuh adalah menyusun butir tes berdasarkan kisi-kisi. Tahap kedelapan adalah uji coba tes yang telah disusun. Idealnya, sebelum tes (soal) diberlakukan kepada siswa, perlu dilakukan uji coba terlebih dahulu. Uji coba ini bertujuan untuk mengetahui apakah tes yang disusun itu benar- benar tes yang baik (shahih dan reliable) atau apakah tes yang disusun itu memiliki tingkat kesulitan yang normal dan benar- benar dapat membedakan kelompok teste yang memiliki kemampuan tinggi dan rendah. Untuk mengetahui hal itu maka, setelah tes dilakukanlah analisis terhadap jawaban siswa (teste). 


\section{Arabi : Journal of Arabic Studies}

Diantara variable yang dianalisis adalah analisis tingkat kesulitan, analisis daya beda, dan analisis reliabilitas.

\section{Evaluasi Pembelajaran Bahasa Arab Berbasis Teknologi Informasi dan Komunikasi}

Perkembangan teknologi komunikasi dapat dimanfaatkan untuk proses belajar mengajar bahasa Arab. Teknologi komunikasi ini dapat berupa media cetak dan elektronik. Media cetak meliputi surat kabar, majalah, buku, dan lain-lain. Media elektronik meliputi komputer, televisi, internet, CD, E-Book, dan lain-lain (Rosyidi, 2009:23). Komputer merupakan jenis media yang secara virtual dapat menyediakan respon terhadap hasil belajar yang dilakukan oleh siswa. Komputer memiliki kemampuan menyimpan dan memanipulasi informasi sesuai dengan kebutuhan. Perkembangan teknologi yang pesat saat ini telah memungkinkan komputer memuat dan menayangkan beragam bentuk media di dalamnya (Rusman, 2013:145). Pembelajaran berbasis komputer merupakan program pembelajaran yang digunakan dalam proses pembelajaran dengan menggunakan software komputer (CD pembelajaran) berupa program komputer yang berisi tentang muatan pembelajaran meliputi judul, tujuan, materi.

Perkembangan teknologi dan informasi dalam dunia pendidikan tidak hanya dimanfaatkan sebagai sumber belajar saja, tapi bisa dimanfaatkan untuk melakukan kegiatan evaluasi pembelajaran. Banyak software yang telah dikembangkan sebagai alat evaluasi dalam pembelajaran yang berbasis teknologi informasi dan komunikasi, seperti: Power Point, Adobe Flash, Hot Potatoes, Wondershare Quiz Creator, dan lain-lain. Dengan program-program tersebut, guru dapat membuat tes bahasa Arab berbasis TIK yang menarik dan peserta didik dapat mengerjakan soal-soal dimana saja tanpa terikat oleh waktu.

Tes selalu dihubungkan dengan cara untuk mengetahui kemampuan siswa dalam penguasaan materi. Hasil tes menjadi salah satu tolak ukur guru dalam membuat keputusan terhadap peserta didik misalnya untuk kenaikan kelas atau kelulusan. Sebelum adanya tes berbasis komputer, tes masih dilakukan dalam bentuk kertas- kertas. Seiring perkembangan teknologi informasi, berkembang pula program-program komputer untuk membuat tes. Program-program ini dapat dimanfaatkan guru dalam membuat tes yang berbasis komputer dan internet.

Menurut Bartram (dalam Hernawati, tanpa tahun: 3) ada empat bentuk model tesberbasis komputer dan internet yang dikembangkan oleh ITC, yaitu :

1. Terbuka (Open Mode); Tes dengan model terbuka seperti ini, dapat diikuti siapapun dan tanpa pengawasan siapapun, contohnya tes yang dapat diakses secara terbuka di internet. Peserta tes tidak perlu melakukan registrasi peserta.

2. Terkontrol (Controlled Mode); Tes dengan model seperti ini, sama dengan tes dengan model terbuka yaitu tanpa pengawasan siapapun, tetapi peserta tes hanya yang sudah terdaftar, dengan cara memasukkan username dan password

3. Supervised Mode; Pada model ini terdapat supervisor yang mengidentifikasi peserta tes untuk diotentikasi dan memvalidasi kondisi pengambilan tes. Untuk tes di internet mode ini menuntut administrator tes untuk meloginkan peserta dan mengkonfirmasi bahwa tes telah diselesaikan dengan benar pada akhir tes.

4. Managed Mode; Pada model ini biasanya tes dilaksanakan secara terpusat. Organisasi yang mengatur proses tes dapat mendefinisikan dan meyakinkan unjuk kerja dan spesifikasi peralatan di pusat tes. Mereka juga melatih kemampuan pegawai/staff untuk mengontrol jalannya tes.

Ada banyak keuntungan melakukan tes melalui komputer, diantaranya mengijinkan melakukan tes di saat yang tepat bagi peserta, mengurangi waktu untuk pekerjaan penilaian tes dan membuat laporan tertulis, menghilangkan pekerjaan logistik seperti mendistribusikan, menyimpan dan tes menggunakan kertas (Hernawati, tanpa tahun: 3). Tes dengan menggunakan komputer lebih menarik bagi siswa dan guru tidak memerlukan waktu banyak untuk mengoreksi 
hasil tes siswa. Tes berbasis komputer, biasanya akan langsung memberikan feedback yang artinya komputer sendiri yang akan mengoreksi tugas siswa.

Bentuk tes yang dapat dikembangkan dengan menggunakan fasilitas teknologi informasi dan komunikasi yaitu Tes Objective: True - False (benar salah), Multiple Choice (pilihan ganda), Multi Select (pilihan ganda asosiasi), dan Mathcing (menjodohkan). Sedangkan Tes Non Objective: Jumble exercise(menyusun huruf/kata), Fill in the Blank(close activity) (melengkapi/jawaban singkat), dan Crossword (teka-teki silang). Beberapa contoh software yang dikembangkan untuk pengembangan media pembelajaran berbasis teknologi informasi dan komunikasi seperti WebCT, Macromedia Authorware, Macromedia Flash, Knowledge Presenter, Hot Potatoes, eXe, Quiz Maker, dan sebagainya (Prayitno, 2013).

Selain software-software tersebut digunakan untuk membuat media pembelajaran. Selain software untuk membuat media, terdapat software yang digunakan untuk membuat tes interaktif, salah sat unya adalah Wondershare Quiz Creator. Software ini sangat mudah digunakan dan model soal yang disediakan sangat banyak yaitu 9 model. Selain model soal, software ini dapat menambah suara dan gambar. Suara atau audio ini dapat digunakan untuk menguji kemahiran mendengar (maharah 'istima').

\section{Pembuatan Soal-Soal Bahasa Arab dengan Wondershare Quiz Crator}

Wondershare Quiz Creator adalah salah satu perangkat lunak yang dapat membuat tes dan kuis dengan beberapa tipe soal. Ada 9 tipe soal yang disediakan oleh software Wondershare Quiz Creator yaitu true/false, multiple choice, multiple response, fill in the blank, matching, sequence, word bank, click map, dan short essay. Dengan tipe tipe soal yang berbeda-beda dalam Wondershare Quiz Creator, evaluasi akan lebih menarik.

Beberapa fasilitas yang tersedia dalam Wondershare Quiz Creator, selain dari sisi kemudahan penggunaan (user friendly) soal-soal yang dihasilkan, diantaranya yaitu (a) fasilitas umpan balik (feed-back) berdasar atas respon/jawaban dari peserta tes, (b) fasilitas yang menampilkan hasil tes/score dan langkah-langkah yang akan diikuti peserta tes berdasar respon/ jawaban yang dimasukkan, (c) fasilitas mengubah teks dan bahasa pada tombol dan label sesuai dengan keinginan pembuat soal, (d) fasilitas memasukkan suara dan warna pada soal sesuai dengan keinginan pembuat soal, (e) fasilitas hyperlink, yaitu mengirim hasil/score tes ke email atau Ims, (f) fasilitas pembuatan soal random, (g) fasilitas keamanan dengan user account/password, dan (h) fasilitas pengat uran tampilan yang dapat di modifikasi (Hernawati, 2009: 1) .

Dengan Wondershare Quiz Creator, pengguna atau guru dapat membuat dan menyusun soal dengan bentuk yang berbeda-beda sesuai dengan model soal yang terdapat dalam software ini. Wondershare Quiz Creator menyediakan sembilan macam jenis model pertanyaan yaitu:

1. True / False, untuk membuat pertanyaan dengan model menjawab benar atau salah

2. Multiple Choice, untuk membuat pertanyaan dengan jawaban pilihan ganda

3. Multiple Response, untuk membuat pertanyaan dengan jawaban pilihan ganda multiple answers (jawaban benar lebih dari satu)

4. Fill In The Blank, untuk membuat pertanyaan dengan cara menjawab mengisi area yang kosong dengan alternatif jawaban yang telah diatur.

5. Matching, untuk membuat pertanyaan dengan cara menjawab memasangkan dua kata/kalimat kiri dan kanan.

6. Sequence, untuk membuat pertanyaan dengan cara menjawab mengurutkan jawaban dari atas kebawah

7. Word Bank, untuk membuat pertanyaan dengan cara menjawab memasangkan kata-kata yang ada dengan kalimat pernyataan.

8. Click Map, untuk membuat pertanyaan dalam bentuk gambar dan cara menjawabnya dengan cara mengklik pada area tertentu dalam gambar sesuai dengan pertanyaannya.

9. Short Essay, untuk membuat pertanyaan isian yang sederhana 


\section{Arabi : Journal of Arabic Studies}

Dengan sembilan model pertanyaan dan semua fasilitas yang disediakan oleh Wondershare Quiz Creator seperti gambar, video, dan suara, guru dapat membuat tes berbasis TIK untuk semua komponen bahasa yang mencakup unsur-unsur bahasa (ashwat bahasa Arab, mufrodat bahasa Arab, dan tarkib/ qowaid/tata bahasa), dan tes keterampilan bahasa ( keterampilan istima, keterampilan qiro'ah, dan keterampilan kitabah) kecuali keterampilan berbicara atau kalam.

Wondershare Quiz Creator memiliki beberapa keunggulan dibandingkan software lainnya seperti mudah dipelajari, programnya mudah dijalankan sehingga membuat evaluasi pembelajaran lebih cepat, bisa dimasukkan gambar serta suara, dan terdapat feedback bagi siswa atas usaha mereka. Selain memiliki keunggulan, Wondershare Quiz Creator juga memiliki kelemahan dalam membuat soal yang berbahasa Arab. Ketika soal-soal yang telah dibuat diterbitkan dalam bentuk flash maka susunan kalimatnya akan kacau. Tetapi, jika diterbitkan dalam bentuk html maka soal tidak kacau dan tetap. Untuk itu perlu ketelitian lebih dalam membuat soal-soal bahasa Arab.

Aplikasi WQC dapat diunduh di wondershare.com. Setelah diunduh dan diinstall maka akan muncul gambar WQC di dekstop. Untuk menjalankan aplikasi ini dengan klik dua kali atau klik kanan lalu klik open. Akan muncul layar WQC dan klik create a new quiz. Pada menu bar WQC terdapat terdapat menu-menu yaitu question untuk menambah pertanyaan baru, quiz properties untuk mengatur properti kuis, player template untuk mengatur background kuis, preview untuk mengecek kuis sebelum diterbitkan, dan publish untuk menerbitkan atau mempublish soal atau tes menjadi format yang bisa di jalankan oleh palikasi yang lain. Adapun tampilan WQC disajikan pada gambar 1 .

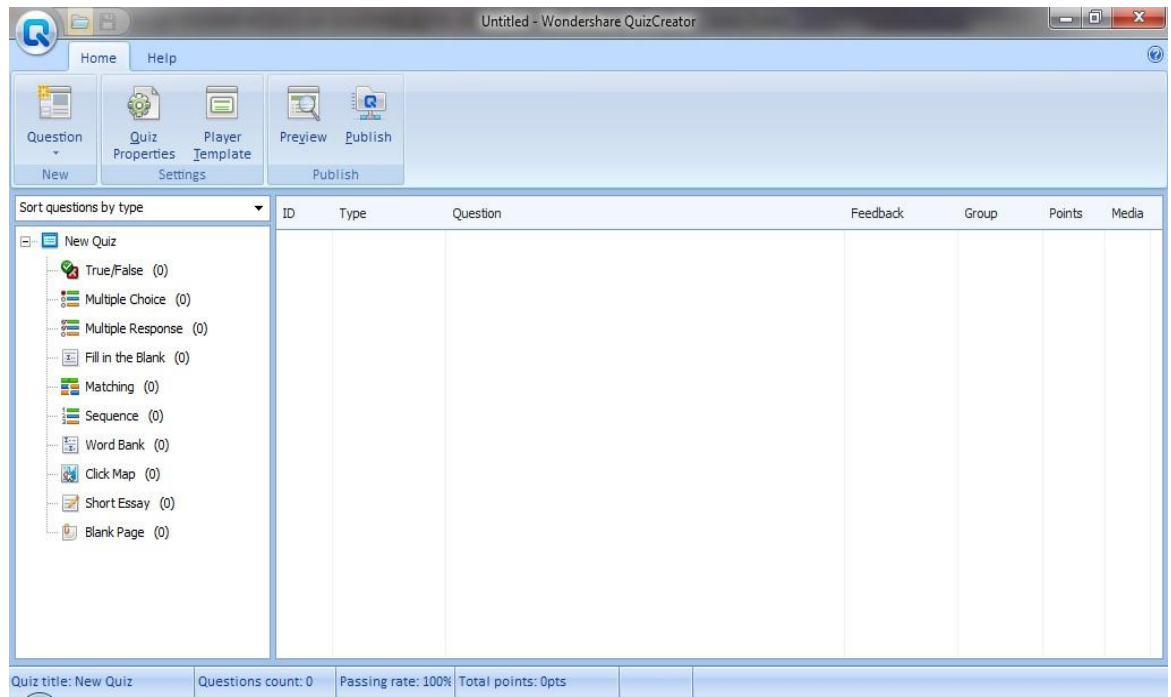

Gambar 1 Tampilan Aplikasi Wondershare Quiz Creator

Sebelum membuat soal, guru harus mengatur quiz properties yang terbagi menjadi lima bagian yaitu Quiz Information, Question Setting, Quiz Result, dan Acces Control. Gambar 2 adalah tampilan dari properties quiz. 


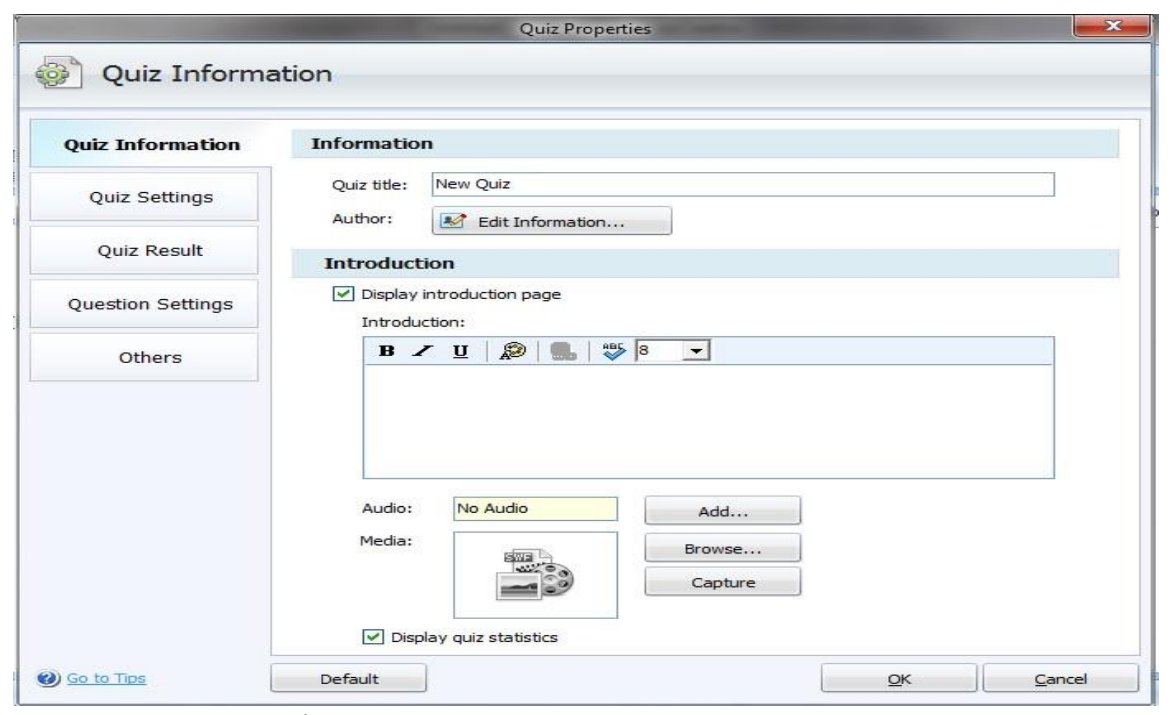

Gambar 1 Tampilan dari Quiz Properties

Quiz information untuk menampilkan informasi yang berkaitan dengan quiz yang dibuat. Guru atau pembuat soal dapat menambahkan judul tes, data diri pembuat soal, dan tampilan pembukaan. Quiz setting terdiri atas Quiz Result Type yang digunakan untuk memasukan batas nilai untuk dinyatakan lulus. Time Limit untuk mengatur waktu seberapa lama tes itu dikerjakan. Jika tidak di centang maka quiz akan jalan terus sampai pengguna menekan tombol submit. Randomization untuk mengatur tampilan soal secara urut atau acak. Answer Submision terdapat dua pilihan untuk mensubmit jawaban, jika dipilih Submit one question a time maka setiap satu soal pengguna harus mengklik tombol submit untuk melanjutkan ke soal selanjutnya dan jika Submit all at once artinya semua soal dijawab terlebih dahulu setelah itu klik tombol submit dan centang Show Correct Answer after Submision untuk menampilkan jawaban yang betul.

Question Result berfungsi untuk mengatur apa yang akan ditampilkan jika siswa atau pengguna berhasil atau gagal dalam tes. Dalam kotak when user passes, guru dapat menambahkah suara, gambar dan tulisan " atau "أنت ناجحوك" begitu juga pada kotak when user fails. Selain itu, guru dapat menambahkan quiz statistic. Quiz statistic digunakan untuk menampilkan statistik kuis pada halaman hasil. Question Setting digunakan untuk mengat ur nilai tiap jawaban benar dari tiap soal dan tingkat kesulitan dari quiz secara keseluruhan. Jika guru atau pembuat soal ingin mengacak pertanyaan dan jawabannya diacak, maka guru dapat mengklik atau menyentang Shuffle question dan Shuffle Answers. Font Properties digunakan untuk merubah font soal atau pertanyaan dan juga jawaban baik jenis font, tebal, dan sebagainya. Untuk bahasa Arab, guru bisa menggunakan font traditional Arabic atau sakkal majalla. Feedback properties untuk memberikan umpan balik pada setiap jawaban yang benar atau salah. Feedback properties bisa diisi dengan kalimat, gambar, dan suara yang lebih menarik buat siswa misalnya jika jawaban benar diganti menjadi " :- صحيح". Jika guru ingin memproteksi tes atau kuis, maka guru tinggal klik others lalu centang access with password only dan memasukkan password.

Setelah mengatur tampilan, langkah selanjutnya membuat soal atu pertanyaan. Dalam WQC tersedia sembilan tipe soal. Untuk membuat pertanyaan dengan klik pada tombol tipe soal tersebut misalnya tipe soal true / False. Untuk jenis pertanyaan ini hanya masukan peryataan kemudian tentukan peryataan ini betul atau salah dengan cara mencentang pada pilihan yang ada. Klik ok untuk selesai atau preview untuk melihat hasilnya seperti apa. Gambar 3 adalah tampilan pembuatan soal atau pertanyaan. 


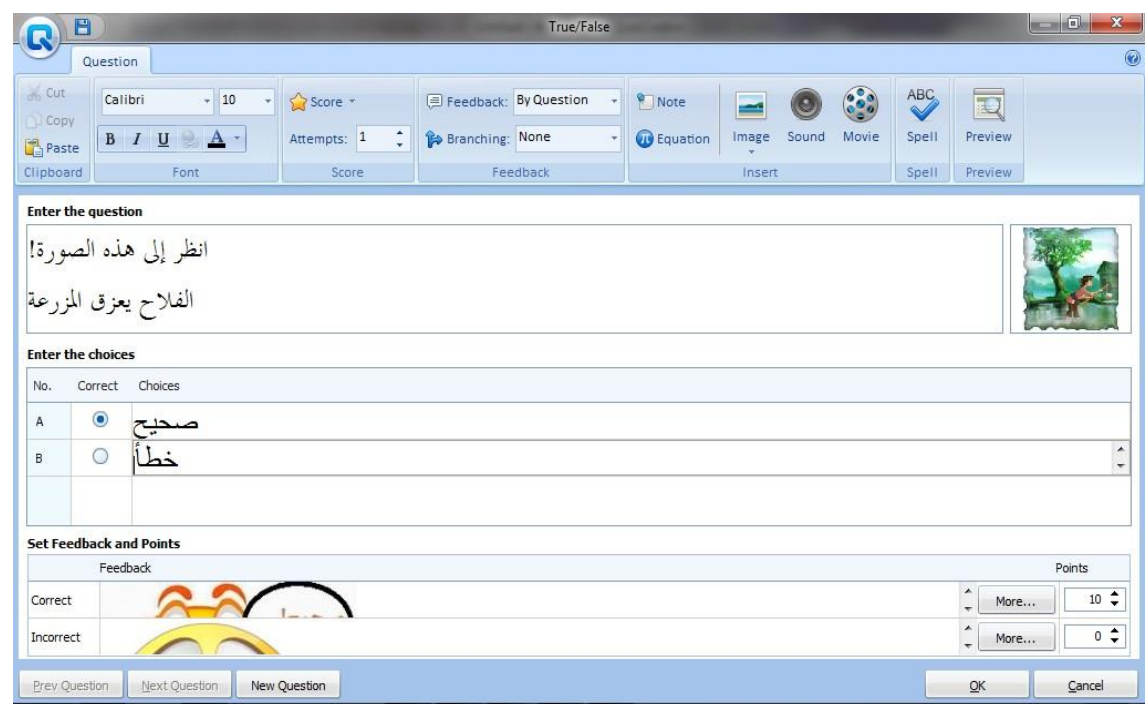

Gambar 3 Tampilan Pembuatan Soal atau Pertanyaan

Tampilan menu pada tampilan pembuatan soal sudah seperti Microsoft Word sehingga mudah digunakan. Guru atau pembuat soal bisa menambahkan gambar, sound dan video. Guru dapat membuat soal untuk maharah istima' karena aplikasi ini didukung dengan suara dan video. Untuk membuat pertanyaan dengan model soal yang lain hampir sama dengan membuat pertanyaan True/False yaitu dengan memasukkan pertanyaan, jawaban dan menandai jawaban yang benar. Jika tampilan dari kuis atau tes kurang menarik, guru dapat Merubah tampilannya di player template. Di dalamnya telah disediakan berbagai template. Adapun contoh template disajikan pada gambar 4 .

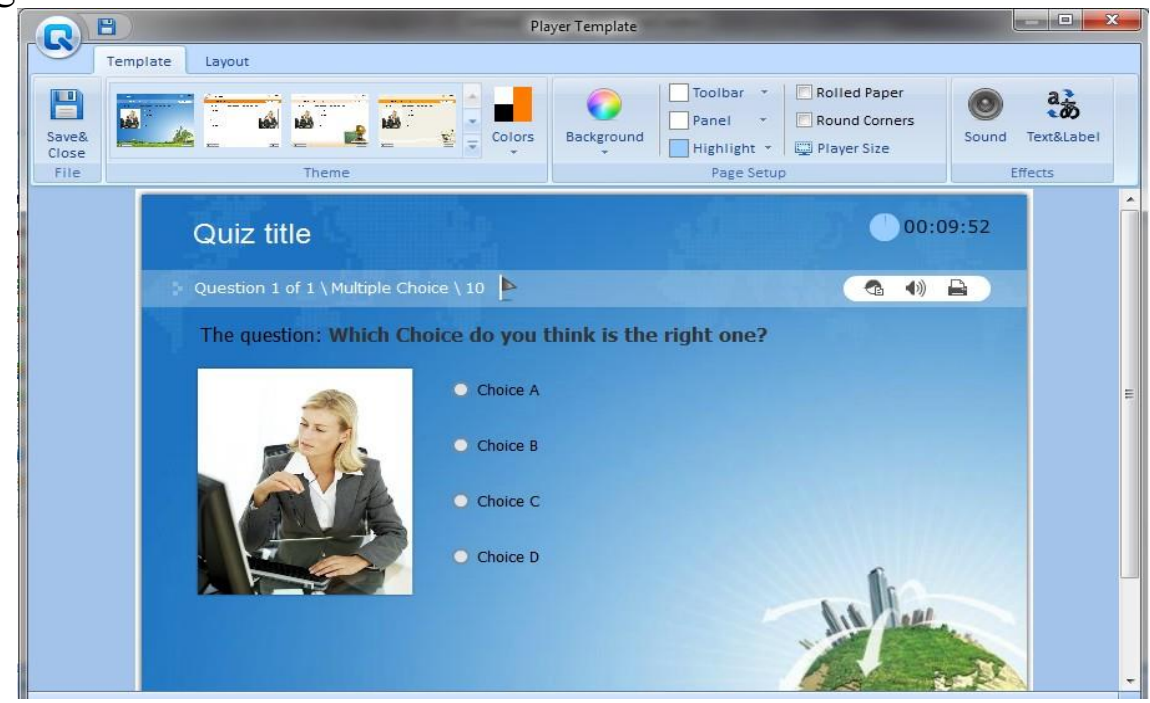

Gambar 4 Contoh Template Kuis atau Tes

Langkah selanjutnya adalah menerbitkan soal tes yang telah dibuat. Klik pada menu publish, kemudian pilih type file yang telah disediakan yaitu web, LMS, CD/Exe, dan word/Excel. Jika guru atau pembuat soal ingin memasukkannya dalam power point maka gunakan tipe web. Klik tombol web dan masukan pada folder yang sama dengan file power point yang akan menggunakan evaluasi ini. Setelah itu, klik publish dan proses akan berjalan, dan klik finish. Untuk melihat hasilnya klik Vire the Quiz, sedangkan untuk membuka tempat tes di simpan dengan klik Open the Folder. Gambar 5 merupakan soal True/False dengan menggunakan Wondershare Quiz Creator. 


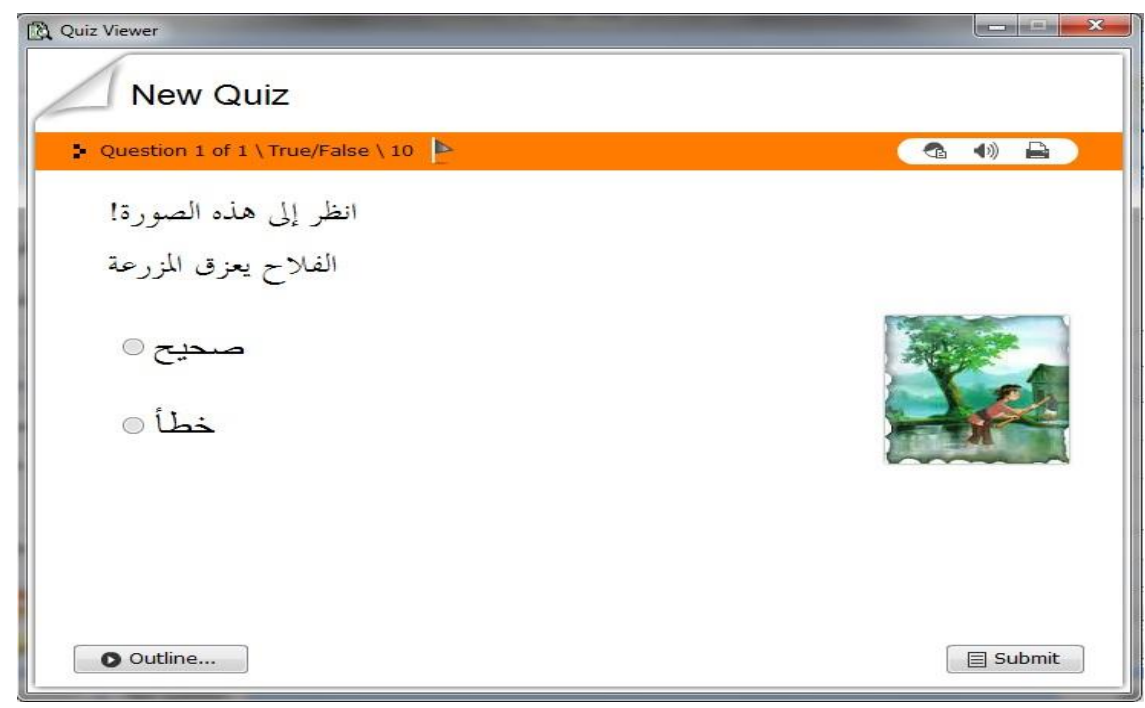

Gambar 5 Soal True/False dengan Wondershare Quiz Creator

Pembuatan soal Bahasa Arab dengan menggunakan Wondershare Quiz Creator lebih mudah dan tidak memerlukan banyak waktu. Siswa akan tertarik dan semangat dalam mengerjakan soal. Dengan Wondershare Quiz Creator, tes akan lebih menantang karena dibatasi oleh waktu dan pengacakan soal atau pertanyaan. Tes akan aman dengan password atau domain hosting batas. Aplikasi ini juga memberikan review dan umpan balik.

\section{Simpulan}

Tes adalah cara untuk mengetahui kemampuan siswa dalam menguasai materi bahasa Arab. Hasil tes ini menjadi salah satu bahan guru bahasa Arab dalam membuat keputusan terhadap peserta didik seperti untuk kenaikan kelas atau kelulusan. Sebelum adanya tes berbasis komputer, tes masih dilakukan dalam bentuk kertas. Seiring perkembangan teknologi informasi,maka berkembang pula aplikasi pembuat tes.

Perkembangan teknologi informasi dan komunikasi telah menyediakan program, software, atau aplikasi dalam membuat media pembelajaran dan alat evaluasi. Salah satu software yang digunakan dalam membuata evaluasi pembelajaran bahasa Arab adalah Wondershare Quiz Creator. Wondershare Quiz Creator adalah salah satu perangkat lunak yang dapat membuat tes dan kuis dengan beberapa tipe soal. Ada 9 tipe soal yang disediakan oleh software Wondershare Quiz Creator yaitu true/false, multiple choice, multiple response, fill in the blank, matching, sequence, word bank, click map, dan short essay. Dengan tipe soal yang berbeda-beda, evaluasi Bahasa Arab akan lebih menarik.[]

\section{Daftar Rujukan}

Asrori, Imam, dkk. 2012. Evaluasi Pembelajaran Bahasa Arab. Malang: Misykat

Asrori, Imam, dkk. 2006. Evaluasi Pembelajaran Bahasa Arab. Malang: Misykat

Arifin, Zainal. 2014. Evaluasi Pembelajaran. Bandung: PT Remaja Rosdakarya

Arikunto, Suharsimi. 1999. Dasar-Dasar Evaluasi Pendidikan. Jakarta: Bumi Aksara

Hernawati, Kuswari. 2009. Membuat Quiz/ Evaluasi Dengan Wondershare Quiz Creator, (Online), (http://staff.uny.ac.id/sites/default/files/pengabdian/kuswari-hernawati-ssi-mkom/modulwondershare.pdf), diakses 5 Mei 2016

Hernawati, Kuswari. Tanpa Tahun. Evaluasi dan Penilaian Interaktif BerbasisWeb, (Online), (http://staff.uny.ac.id/sites/default/files/penelitian/Kuswari\%20 


\section{Arabi : Journal of Arabic Studies}

Hernawati,\%20S.Si.,M.Kom./Evaluasi\%20\%20dan\%20Penilaian\%20Interaktif\%20Berbasis \%20Web.pdf), diakses 6 Mei 2016

Ismail, Taufik bin. dkk. "Istiratijiyat al-Ta'alum al-Mubasyar Lada al-Thalabah al-Mutakhashishin fi al-Lughah al-'Arabiyah bi Istikhdam Barnamaj ATLAS.ti" Arabiyat : Jurnal Pendidikan Bahasa Arab dan Kebahasaaraban, Vol. 3, No. 2, 2016.

Matsna HS, Moh, dan Mahyudin, Erta. 2012. Pengembangan Evaluasi dan Tes Bahasa Arab. Tanggerang Selatan: AlKitabah

Prayitno, Wendhie. 2013. Evaluasi Pembelajaran Berbasis TIK, (Online), (http://lpmpjogja.org/evaluasi-pembelajaran-berbasis-tiǩ/), diakses 6 Mei 2013

Rolisca, Rendik Uji Candra, dan Achadiyah, Bety Nur. 2014. Pengembangan Media Evaluasi Pembelajaran Dalam Bentuk Online Berbasis E-Learning Menggunakan Software Wondershare Quiz Creator dalam Mata Pelajaran Akuntansi SMA Brawijaya Smart School.
Jurnal
Pendidika
Akuntansi
Indonesia,
12
(1),
(Online),

(http://journal.uny.ac.id/index.php/jpakun/article/view/2706/2264), diakses 5 Mei 2016

Rosyidi, Abdul Wahab. 2009. Media Pembelajaran Bahasa Arab. Malang: UIN-Malang Press

Rusman. 2013. Belajar Dan Pembelajaran Berbasis Komputer: Mengembangkan Profesionalisme Abad 21. Bandung: Penerbit Alfabeta. 